\author{
Pavlichenko L. V., \\ $P h D$ in Linguistics, \\ Taras Shevchenko National University of Kyiv
}

\title{
PRAGMATIC PECULIARITIES OF CONFLICTS RESOLUTION IN THE INTERROGATION DISCOURSE
}

Summary. The article analyses the discourse of pre-trial investigation as an oral subtype of pre-trial communication of the institutional legal discourse, which is characterized by a number of invariant (constitutive) features and their variations depending on the respective procedural status of interrogated persons (and namely, a suspect, an accused person, a witness, a victim). The constituent features of the DPI [The discourse of pre-trial investigation], which ensure its status as a separate subtype of pre-trial communication, are: the global institutional goal and the goals that follow from it; a status and roles distribution of communicators; a type of social and communicative relations between participants of interrogation; the specific features of the place and the time of communication; stereotypical relevant linguistic, as well as pragmatic and linguistic features; the institutional form of the interrogation as a type of a dialogue communication with the narrative inclusions. The main emphasis of the article is placed on the purpose of the discourse of the pre-trial investigation, that is on the obtaining of the information necessary for the investigation of a case from interrogated persons with different procedural status (suspect, witness, accused, victim). The global purpose is implemented through local goals that determine the relatively stereotypical scenario of the interrogation and the communicative roles of its participants. To further cover various aspects, it is necessary to determine the following main objectives of the interrogation: obtaining and summarizing information about the crime, its circumstances, participants and motives of a crime; establishing the degree of validity of the reported during the interrogation information; the use of communicative actions that may induce the suspect to confess to the crime. The variation of the discourse of pre-trial investigation depends on the procedural status of interrogated persons. Th conducted analysis of the material proved, that it is a procedural status of an interrogated person that causes restructuring of the entire interrogation.

Key words: strategy, tactics, investigator, accused, victim, witness.

Introduction. Due to the importance of the institutional discourse as an object of modern linguistic research, at present there is constant and growing interest of modern linguists in the study of its various types. In the Ukrainian and Russian linguistics the following types of institutional discourse are analysed in various aspects: argumentative $[27 ; 1 ; 3]$, political [19; 23; 17], artistic [2; 4], business discourse [20], legal and linguistic [18]; scientific [12], pedagogical [7], legal [8; 9; 16; 17]; advertising [11]), etc.) in the context of their linguistic, suggestive, manipulative, argumentative, pragmatic, cognitive, semiotic specific features.

The institutional discourse is characterized by a number of linguistically relevant features, the most important of which are the purpose of communication, the representative communicative function of the participants and the fixed typical circumstances of communication [14].

Summarizing the opinions of scientists, we can conclude about such constitutional features of institutional discourses as the stereotypes of linguistic means, a specific institutional goal and participants as the representatives of the institute agents and the clients. Each institutional discourse is characterized by certain correlation between the status and personal components.

Problems of the language of law are widely discussed by Ukrainian and foreign linguists: Baranov, 1990, 2011; Varnavskikh, 2004; Vasilyanova, 2007; Golev, 1999; Dubrovskaya, 2010; Zaytseva, 2011; Koval, 2006; Kolesnikova, 2007; Skuratovskaya, 2002; Coulthard, 2010; Harris, 1952; Heydon, 2005; Shuy, 1996, and others.

Legal discourse is a kind of institutional discourse that has a clear purpose, defined participants, and a template for the deployment of a communicative situation.

The discourse of pre-trial investigation is a type of legal discourse and one of the types of institutional communication. Compared with the discourse of the court investigation, we do not have a comprehensive linguistic study of DPI. While the issue of linguistic consideration and the study of the peculiarities of the discourse of court sessions originates from the the early years of forensic linguistics, which defines its object as description of the communicative peculiarities of the litigations. The questions of studying the discourse of court sessions, the specifics and functions of judicial discourse, speech strategies in the lawyer's discourse, means of speech influence and arguments have long interested linguists $[9 ; 16 ; 25 ; 15]$. On the one hand, this discourse is the discourse of individual trials or their stages [2]. On the other hand, judicial discourse is recognized by linguists as a generalizing notion that combines various discourses and allows to identify typical characteristics and general patterns of judicial communication, in particular the discourse of prosecution and defence, the discourse of judges [12], etc.

According to Dubrovskaya [9, p. 10], judicial discourse is a verbal expression of the communication process in the course of a judicial process that is considered in the socio-historical, national-cultural, concrete situational context, taking into account the characteristics and intentions of the communicants. In this case, the ultimate goal of the process is to solve the legal conflict and change the legal situation.

The variation of the pre-trial interrogation discourse according to the procedural status of interrogated persons. The variation of the discourse of pre-trial investigation is determined by the procedural status of interrogated persons.

According to the preliminary analysis of the material as well as the review of special legal literature, it is a procedural status of an interrogated person that causes restructuring of the entire speech interrogation event. 
Despite a different procedural status of "a victim" and "a witness", their communicative behaviour in the discourse of interrogation has common features, since both are usually interested in clarifying the circumstances of the case and in cooperation with an investigator. On the other hand, there are similar scenarios of the behaviour of "suspect" and "accused", who are often not interested in disclosing a crime and initiate a conflict type of communication. So, such variants of the "investigator-interrogated person" dyad, as "investigator-victim/witness" and "investigator-suspect/accused", determine the variational realization of the above-mentioned constitutive parameters of interrogation defining its discursive types.

The questioning of a victim and a witness is an example of a nonconflict type of communication, since a victim is the person who is most interested in disclosing a crime or an offence.

In particular, during the interrogation of a witness, the global purpose of the discourse of interrogation is specified by such goals as:

1) revealing the circumstances of a crime;

2) identification of characteristics of persons who are involved in a crime;

3) identification of motives of a crime known to a witness/ victim;

4) assumptions about their own versions of a crime;

5) clarification of relations between victims (or witnesses, if necessary) and suspects or accused persons;

6) h) clarification, verification and interpretation of the information provided by a victim/witness.

Such goals are set by the appropriate themes, which correlate with a global goal "to facilitate the disclosure of a case". The leading concept for such a subset of the DPI is the concept of "cooperation" in the dyad "investigator-witness" and the concept of "protection" in the dyad "investigator-victim", their pragmatic and linguistic potential being realized through means of positive courtesy as courtesy of cooperation, understanding and encouragement to seek consensus among participants of communication. Preliminary analysis of selected samples of DPI showed that the role of an investigator and an interrogated person in dyads investigator-victim / witness is indexed by implicit and explicit nominating units with semes of "interest", "understanding", "compassion", help, "protection":

(1)

a. Det. Carrasquillo: Well let me help you with that. [36]

b. Det. Baldwin: Brendan, I know you're scared, okay. I understand that, all right. I want to try to help you, okay. [35]

The investigator (and the interrogated person) used slangisms, colloquia, diminutive names as the corresponding in-group markers (You know something a little more, and you are just gonna tell me, You understand that?, I'm gonna turn off the tape at 1645, You gonna help us, (Well, I'm giving you the opportunity, man, to tell me)). [34], disjunctive questions (Det. Weigert: You kinda know better, though, do not you? , Det. Fassbender: I already knew better, they were girls clothes, were not they [36].

Feedback signals, typical for communication of an investigator and a witness/victim, are such as picking up (Yeah), agreeing (0k? $0 \mathrm{k}$ ), repetitive question (who is Victor? - Victor?):

(2)

MacLeod: Who is, who is Victor?

Smith: Victor? I've got, um, my friend. I have a Spanish friend who has a son called Victor [34].

At the same time, the investigator applies bald on-record strategies [28] in questioning of a witness, requesting information in the form of direct non-mitigated questions, legislative acts, etc. ("We will want to know exactly?" "What was it that you bought for that?" to help them to remember forgotten or unintentionally missed facts or to disclose information that a witness or a victim can conceal or distort for the fear of an attack by a suspect or his relatives:

(3)

Agent Feola: You did not know a reason why? I mean was it emotional ... financial ... both ... work ...? [34]

Similarly, a victim may also not always provide objective information, facts, assessments, characteristics by the influence of insults, anger, or other feelings, or if they want to take revenge. In case of refusal by a witness or a victim to give evidence for any reason, an investigator is forced to use manipulative techniques and tactics. During the development of such a scenario, an interrogation of a witness or a victim acquires signs of genre hybridity and comes closer to the interrogation of "a suspect/ an accused".

Of course, more complicated for an investigator is the interrogation of a suspect and an accused. Unlike communicative cooperation between an investigator and a witness, an investigator and a victim, the interrogation of a suspect and an accused, with the exception of the situation where an investigator deals with the confession of the crime, is a conflict discourse, since if involved in a crime, suspects and accused persons may refuse to give evidence or provide false testimony. The communicative conflict that arises as a result of inconsistencies in intentions and strategic programs of communicants who pursue radically different goals in the DPI can result in cognitive dissonance, "the termination of communication, the reluctance of further continuation of communication" [22, p. 185]

(4)

MacLeod: Can I just talk about the time that you were involved in the trade union affairs.

Smith: No comment.

MacLeod: Why? Is there something about this that might embarrass you?

Smith: No comment.

MacLeod: Why did you join Thorn EMI?

Smith: No comment.

MacLeod: Does that cause you something of discomfort?

Smith: No comment [34].

In the dialogue below, the reluctance to continue the interaction by a suspect is explicitly demonstrated in the form of a refusal, which, due to its elliptical conciseness and numerous repetitions re-emphasizes the conflict of communicative interaction.

In addition to the communicative conflict, in the discourse of interrogation in the dyads "suspect investigator", "investigatoraccused" we can see the type of interactivity known in the theory of linguistic communication and linguistic pragmatics as a communicative rivalry based on the desire to gain intellectual superiority, to carry out their intentions ( ...), enhance the status of a person [22, p. 185]

(5)

Smith: I do not know what it is, but I'm not going to answer questions that might incriminate me, based on something that I do not have any, anything to do. You are playing around here

MacLeod: No, I'm not.

Smith: If I'm supposed to have met some guy called Victor, while I was out this morning, that, that obviously means something to you, does not it? Does it? [34] 
In the given fragment, the suspect uses a strategy of verbal provocation, which is determined by the researchers as a conflictrelated technology of speech influence, a communicative failure deliberately organized by a speaker [13, pp. 92-104]. In particular, the "emotionally destabilizing tactics of the "direct" ("you are playing around here") and indirect revealing of the investigator ("that obviously means something to you, does not it? Is it?") are amplified emphatically by repeating the question, that performs a syntactic-stylistic function. At the same time, an elliptical structure and anadipolisis in this particular example function as a means of putting pressure on the interlocutor. The provocative strategy of the interrogated person proved to be successful as it has a perlocative effect on the investigator: a speech act of justification ("No, I'm not").

It is important to note that the strategic program for conducting interrogation of a suspect and an accused from the legal point of view is complicated for an investigator by the fact that, unlike witnesses and victims, persons with this procedural status are not held criminally liable for refusal to testify and to give false testimony. In addition, a suspect has the right to refuse to testify, they can meet with a lawyer before interrogation, file complaints about the actions of an investigator, a prosecutor, file a petition, demand verification of the lawfulness of detention.

Consequently, during interrogation of a suspect and an accused person, the global goal of the DPI is specified by such subgoals as:

1) explaining to suspects their rights and explaining what they are suspected of;

2) establishing of psychological contact with a suspect for the implementation of the tasks, development of a strategic tactical program for questioning and avoiding communicative failures;

3) stimulating an interrogated person to provide true and objective evidence in a case when that can testify against him;

4) convincing of an interrogated person to make confession;

5) disclosing of false, incomplete or distorted testimonies, as well as detecting of self-incrimination cases where an accused person or a suspect takes guilt by fear, intimidation or unwillingness to accuse a close person.

Consequences of a conflict and forcing in interrogation are sabotage by an interrogated person, refusal to give evidence and communicative failures:

(6)

MacLeod: Over a period of time you sold the secrets. You sold the classified information to the Russians.

Smith: I've got no comment on that.

MacLeod: I'm sure you have not

Smith: That's right. id.

MacLeod: But your ex-handler, your ex-controller, says you

Smith: Nobody controls me, but I control myself.

MacLeod: (...) And, can you remember what they did to you on that occasion, or what they asked you to undertake?

Smith: I've got no comment on that matter [34].

Other cases of conflict communication between an investigator and a suspect are the misleading of an investigator by false information, distortion of facts, etc.

(7)

a. MacLeod: Did you answer my question?

Smith: You do not have access to my phone, so how do you know if there were any calls anyway. My wife might have said there was a phone call; somebody asked for me, I spoke to it, some guy who I'd never spoken to before. I must add that, and he was talking some mumbo jumbo and, I ... .

b. MacLeod: If it was somebody asking for you, if it was somebody asking for you, how could that be a misdirected phone call?

Smith: Maybe it was somebody who got my name from the phone book, or something [34].

In the example above, the false information provided by an interrogated person is followed by the question of the investigator in the form of a conditional sentence, with the implication in the conditional clause of the fact, that Smith knew the person, who called him (it is repeated twice to focus attention on the most important information).

The success of the dialogue, even in the conflict, depends, first of all, on the linguistic behaviour of an investigator, who should do everything possible to prevent sabotage, detect and remove communicative failures through re-formulation, clarification, and additional questions.

(8)

MacLeod: Do you know any other Victors?

Smith: I do not think so. Not, not at the present. I do not know maybe I knew some in the past.

MacLeod: Have you known any Victors in the past? [34]

Consequently, an investigator involves the elements of argumentative discourse. According to A. Belova [3, pp. 109-110], the argumentative discourse contains linguistic units and constructions, non-verbal components and extralinguistic factors used and taken into account by an argumentator in order to maximize persuasive influence on a recipient. The semantic organization of such a discourse influences its argumentative sounding and stimulatory efficacy.

A preliminary study of the material showed that investigators used different methods of argumentation. One of the most common is the descending argumentation: from the most convincing arguments to less significant secondary circumstances:

(9)

MacLeod: (...) I'm going to reproduce the exhibit JS/40, produced earlier in this interview. That's a letter to $\mathrm{Mr}$ Smith from somebody called Williams. Let's talk about Mr Williams again. Have you had any more thoughts on who this Williams is?

Smith: I do not know anyone by the name of Williams (...).

MacLeod: Well, clearly, he must have known you, to have written to you, and I find it curious that the letter should have been in the same envelope containing $£ 2,000$ and containing and containing other pieces of paper scrap paper giving directions their rendezvous points [34].

The ascending argumentation is also widely spread, that is from the circumstances to the gradual proof of the very fact of the crime:

(10)

MacLeod: You have told me that you were in the telephone box, and that you picked up the telephone receiver to make a call.

Smith: (...) if you have photographic evidence that I did, then I can't deny it, but I'm not absolutely sure that I did.

MacLeod: Ok. But you were in the telephone box, whether you be, lifted it or not.

Smith: In the vicinity of the telephone box.

MacLeod: In the vicinity. (...) Can you tell me what road did you go up then?

Smith: I then went up Cardinal Avenue. 
(...) MacLeod: So, you went up Cardinal Avenue, you made some enquiries, and what route did you take then?

Smith: I then came straight back down Cardinal Avenue.

MacLeod: I am now going to show Mr Smith a coloured photograph. Do you recognise that photograph,or do you recognise yourself?

Smith: Yes, that's me (...)

MacLeod: Yes, of course you were. And you're right beside the telephone box.

Smith: Yes, I'm just, I didn't, that's completely in accord with my story.

MacLeod: I'll show a third coloured photograph to Mr Smith. Do you recognise the road?

Smith: Yes, Hollybush Road, (...)

MacLeod: And, in actual fact, this further photograph shows you inside the telephone box.

Smith: Well, obviously, I have been, yes [34].

In the above section of the interrogation, the purpose of the investigator is to prove that an interrogated person is telling lies, and he really was in a telephone booth. For this purpose, the investigator through the direct repetitive questions explains in detail the route of Smith and provides relevant photographs, forcing him to confess.

The inductive method of argumentation (from arguments to a conclusion) correlates with an ascending argumentation.

(11)

MacLeod: I will be happy to meet you, as before, at the recreation in October. That clearly suggests that there is ongoing association with the sender and receiver, does not it? Does that, does that [34].

Among other methods of argumentation used by investigators (rarely - interrogated persons), we've identified counterargumentation, when an investigator gives his own arguments as a refutation of the arguments of an interrogated person (a similar strategy can be applied and by an interrogated person):

(12)

Smith: I've got nothing to worry about. That letter was from someone else, to me, and I, I do not understand the message in it.

MacLeod: You do not understand the message in it? I think that's a fairly straight forward message. I mean you're an intelligent man, you're not an idiot, you've, you've got a university degree, and you're telling me you do not understand the contents of a simple letter like that? [34].

Thus, in the example above, the argument of the interrogated person about the incomprehensible content of the letter was refuted by the counterargument of the investigator about the university education of the interrogated person and too simple style and content of the letter.

Conclusions. The participants in the DPI are investigators and interrogated persons, who, depending on their status, may act as a suspect, an accused, a witness or a victim, performing various status-communicative roles. Data about the participants, including the full name and institutional status, are implemented by lexical and syntactic formulae. Such method of addressing an interrogated person, as appealing to him in the process of interrogation, especially in a diminutive form, is, on the one hand, a marker of positive politeness and, on the other hand, an index of unequal role status and communicative rights of the participants of the interrogation. Other manifestations of vertical communicative relations between the participants in the DPI are the right of an investigator for the communicative initiative: to direct the interrogation scenario, to implement and change the topic, to intercept the communicative initiative, to apply legislative acts (prescriptive) and direct questions that are threatening the face of an interrogated person.

Pragmatic presuppositions on socio-psychological peculiarities of interrogated persons, their intellectual abilities, values, belonging to a particular sociocultural or ethnic group, subgroup, age, gender, and especially those relating to the circumstances of the crime are particularly important for the optimization of the discourse of interrogation. Such presuppositions are part of the discursive personality of the investigator in DPI, since they determine the choice of intralingual means, manipulative techniques, and communicative tactics, including the adjustment for the linguistic register of an interrogated person, the use of politeness strategies, the «deduction» of conversion implicators in the manipulative behaviour of an interrogated person, defining the conditions of success of speech acts, etc.

The variability of the types of DPI by the parameters of local goals, typical topics, linguistic means, pragmatic characteristics and basic values is determined by the procedural status of interrogated persons in role pairs "investigator - victim / witness" and "investigator - suspect / accused", which are homogeneous on the grounds of providing information, a function in the development of the discourse of interrogation and communicative and linguistic, as well as pragmatic manifestations.

\section{References:}

1. Баранов А.Н. Лингвистическая теория аргументации (когнитивный подход) : автореф. дисс. док. филол. наук. Москва, 1990. 48 с.

2. Бехта I.А. Дискурс наратора в англомовній художній прозі. Киев : Грамота, 2004. 304 с.

3. Белова А.Д. Лингвистические аспекты аргументации: Лингвистика. Теория коммуникации. Английский язык. 2-ое изд., перераб. и доп. Киев : Киевский национальный ун-т им. Тараса Шевченко, 2003. 304 с.

4. Бурбело В.Б. Художній дискурс в історії французької мови та культури IX-XVIII ст. : автореф. дис. ... д-ра філол. наук : спец. 10.02 .05 «Романські мови». Ки їв, 1999. 32 с.

5. Варнавских Н.В. Типологические черты речевого поведения русско- и англоговорящих адвокатов (прагматический подход) : дис. ... канд. филол. наук. Ростов-на-Дону, 2004. 132 с.

6. Васильянова И.М. Особенности аргументации в судебном дискурсе : дисс. ...канд. филол. наук : спец. 10.02.19. Тверь, 2007. 206 с.

7. Габідулліна А.Р. Навчально-педагогічний дискурс : категоріальна структура та жанрова своєрідність (на прикладі шкільного предмета «Російська мова») : автореф. дис. на здобуття наук. ступеня докт. філол. наук : спец. 10.02.02 «Російська мова». Київ, 2010. $40 \mathrm{c}$.

8. Голев Н.Д. Юридический аспект языка в лингвистическом освещении. Юрислингвистика. Проблемы и перспективы. Барнаул, 1999. С. 11-58.

9. Дубровская Т.В. Судебный дискурс: речевое поведение судьи (на материале русского и английского языков. Москва : Изд-во «Академия МНЭПУ», 2010. $351 \mathrm{c.}$

10. Зайцева В.В. Когнитивные, коммуникативно-прагматические и языковые особенности допроса в юридическом дискурсе : дисс. на соискание уч. степени канд. филол. Наук : спец. 10.02.19 «Теория языка». Тамбов, 2011. 210 с.

11. Зирка В.В. Манипулятивные игры в рекламе: лингвистический аспект. Днепропетровск : ДНУ, 2004. 294 с.

12. Ільченко О.М. Етикетизація англо-американського наукового дискурсу : автореф. дис. на здобуття наук. ступеня докт. філол. наук: спец. 10.02 .04 «Германські мови». Київ, 2002. 25 с. 
13. Иссерс О.С. Стратегия речевой провокации в публичном диалоге. Русский язык в научном освещчении. № 2(18). Москва, 2009. С. 92-104.

14. Карасик В.И. Язык социального статуса. Москва : ИЯЗ: Перемена, 1992. $329 \mathrm{c}$.

15. Кобзєва О.О. Стратегії та тактики судді в американському судовому дискурсі : дис...канд. наук: спец. 10.02 .04 ; Харк. нац. ун-т ім. В.Н. Каразіна. Харків, 2017. 249 с.

16. Коваль Н.Є. Комунікативно-прагматичні аспекти юридичного дискурсу. Викладання англійської мови як мови фаху в контексті глобалізації університетської освіти. Вип. 1. Львів, 2006. С. 87-97.

17. Колесникова Л.В. Юридический дискурс как результат категоризации и концептуализации действительности (на материале предметно-терминологической области «Международное частное право») : дис. ... канд. филол. наук: спец. 10.02.19 «Теория языка». Ставрополь, 2007. 166 с.

18. Любимов Н.А. К вопросу о правовой коммуникации в законотворчестве. Юрис-лингвистика-3: Проблемы юрислингвистической экспертизы. Барнаул, 2002. С. 132-147.

19. Нагорна Л.П. Політична мова і мовна політика: діапазон можливостей політичної лінгвістики. Київ : Світогляд, 2005. 315 с.

20. Науменко Людмила. Сучасний англомовний бізнес-дискурс в комунікативно-прагматичному та концептуальному висвітленні : монографія ; Київський національний ун-т імені Тараса Шевченка. Інститут філології. Київ : Логос, 2008. 360 с.

21. Павліченко Л.В. Сучасний англомовний дискурс досудового слідства: комунікативно-прагматичний аспект. дис. ... канд. філол. наук: спец. 10.02.04 «Германські мови». Київ, 2018. 250 с.

22. Селіванова О.О. Сучасна лінгвістика: термінологічна енциклопедія. Полтава : Довкілля-К, 2006. 716 с.

23. Серио П. Как читают тексты во Франции. Вступительная. Квадратура смысла: Французская школа анализа дискурса. Москва : ОФО ИГ «Прогресс», 1999. С. 12-53.

24. Скуратовська Т.А. Аргументація в американському судовому дискурсі (на матеріалі справ за участю суду присяжних) : автореф. дис. на здобуття наук. ступеня канд. філол. Наук : спец. 10.02 .04 «Германські мови». Київ. нац. ун-т ім. Т. Шевченка. Київ, 2002. 22 с.

25. Солдатова А.А. Специфика речевых стратегий в адвокатском дискурсе. Права и свободы человека: проблемы реализации, обеспечения и защиты : мат. междунар. науч.-практич. конф. 5-6 июня 2011 г. Пенза - Прага : Научно-издательский центр «Социосфера», 2011. С. 163-166.

26. Фещенко О.В. Інституиійність дискурсу американського слідства) : дис. ... канд. філол. наук: 10.02.04. Харк. нац. ун-т ім. В.Н. Каразіна. Харків, 2017. 234 с.

27. Antaki, C. 1994. Explaining and arguing: The social organization of. London \& Thousand Oaks: Sage.

28. Brown, P., Levinson, S. C. 1987. Politeness: Some Universals in Language Usage. Cambridge : Cambridge University Press.

29. Coulthard, M., Johnson. A. 2010. A Handbook of Forensic Linguistics: Language in Evidence, London, Routledge.
30. Harris, Z. S. 1952. Discourse analysis: A sample text. Language. Vol. 28: 1-30.

31. Hering S. 1996. Computer Mediated Communication: Linguistic, Social and CrossCultural Perspectives. Pragmatics and Beyond Series. Amsterdam: John Benjamins.

32. Heydon G. 2005. The language of police interviewing: A critical analysis. Houndmills, UK. Palgraves Macmillan Inc, 2005.

33. Shuy R.W. 1996. Language Crimes. Oxford: Blekvell.

\section{Illustrative material:}

34. Smith M. J. Police interviews. (Retrieved from: http://Cryptome.org/ smith-inter.zip)

35. MishicotHSTranscript.pdf. (Retrived from: https://www.docdroid. net/2KmgtSR/mishicothstranscript.pdf\#page=3)

36. Transcript of interview of Brendan Dassey. (Retrived from: http:// www.stevenaverycase.org/wp- content/uploads/2016/02/ Brendan-Dassey-Interview-at-School-Transcript-2006Feb27)

Павліченко Л. В. Прагматичні особливості вирішення конфлікту в дискурсі допиту

Анотація. У статті проаналізовано інституційний дискурс досудового слідства як усний підтип досудового спілкування інституційного юридичного дискурсу, який характеризується низкою інваріантних (конститутивних) ознак та їх варіаційними проявами залежно від відповідного процесуального статусу допитуваних осіб (а саме підозрюваний, обвинувачений, свідок, постраждалий). Складовими ознаками ДДС (дискурсу досудового розслідування), що забезпечують його статус окремого підтипу досудового спілкування, є: глобальна інституційна мета та цілі, що з неї випливають; статусно-рольовий розподіл комунікантів; тип соціально-комунікативних відносин між учасниками дискурсу досудового слідства; специфіка місця і часу спілкування; стереотипні відповідні мовні та прагмалінгвістичні особливості; інституційна форма дискурсу досудового слідства як діалогового спілкування з розповідними включеннями. Основний акцент статті буде зроблено на меті дискурсу досудового слідства, тобто на отриманні інформації, необхідної для розслідування справи, від допитуваних з різним процесуальним статусом. Мета дискурсу досудового слідства реалізується через конкретні цілі, що визначають відносно стереотипний сценарій ведення допиту та комунікативні ролі його учасників. Для подальшого висвітлення різноманітних аспектів необхідно визначити такі основні цілі ведення допиту: отримання та узагальнення інформації про вчинений злочин, його обставини, учасників та мотиви вчинення злочину; встановлення ступеня правдивості повідомленої під час допиту інформації; застосування комунікативних дій, які можуть спонукати підозрюваного до зізнання у вчиненому злочину.

Ключові слова: стратегія, тактика, слідчий, обвинувачений, жертва, свідок. 